\title{
Xenophobic Utterances in Juvenal's Satires
}

\author{
Gergő Gellérfi \\ (University of Szeged)
}

\begin{abstract}
The concept of xenophobia appears frequently in articles and monographs dealing with the Satires of Juvenal, where it is applied to the content of the poems, their narrator, and sometimes the poet. Although the usage of this term might seem anachronistic for an ancient context, it should not be dismissed as a speaker in Juvenal presents the features of xenophobia - both from the word's lexical definition and its more complex descriptions, e.g. that one appearing in the Declaration on Racism (2001). However, this speaker is not the narrator of the Satires but rather the central figure of Satire 3, the interlocutor named Umbricius, whose character is purposefully rendered by Juvenal as having different characteristics and views from his narrator. In this article, I present arguments suggesting that Umbricius may rightly be named a xenophobic person, in contrast to the Satires' narrator.
\end{abstract}

\section{Keywords}

Juvenal; satire; Roman literature; xenophobia

This research was supported by the project nr. EFOP-3.6.2-16-2017-00007, titled Aspects on the development of intelligent, sustainable and inclusive society: social, technological, innovation networks in employment and digital economy. The project has been supported by the European Union, co-financed by the European Social Fund and the budget of Hungary. 
Juvenal was "accused" of discrimination by scholars more times than maybe any other ancient author. Several studies written on the Satires name Juvenal's poems, his narrator or sometimes the poet himself as homophobic, misogynist and xenophobic quite often; moreover, the concept of racism is also mentioned occasionally in connection with the latter. The common feature of these phenomena is the fully or at least partially irrational discrimination, fear or hatred of a given group. Juvenal's supposed homophobia is mainly deducted from Satires 2 and 9, while the accusation of misogyny originates in Satire $6 .{ }^{1}$ Concerning xenophobia, multiple scholars emphasize the difference between the treatment of certain groups of foreigners, ${ }^{2}$ while Crompton makes an important observation concerning the closure of Satire 2 - speaking about homosexuality: "Given his xenophobia, one might expect Juvenal to blame these alarming new tendencies on foreign influences, but he finds the source of the 'plague' in Rome itself. Rome, he thinks, will infect the barbarians." The present article deals with the issue of xenophobia and racism, focusing on the question whether the only possible reading of the Satires is that their narrator ${ }^{4}$ is a xenophobic and/or a racist speaker based on his treatment of foreigners? ${ }^{5}$

Before examining the Juvenalian passages mentioning foreigners, the concept of xenophobia itself, having numerous different definitions, needs to be clarified. The expres-

1 To quote just a few examples: Fone (2000: p. 54): "All this derision of pathici and cinaedi foreshadows some darker chapters in human history...”; Bond (1979: p. 418): "Cato and Juvenal both belonged to the same misogynistic tradition...”; Braund (2004: p. 230): "Juvenal's satiric persona is the same angry extremist, with the addition of misogyny to his homophobia, chauvinism, and other bigotries.”

2 Watts (1976: p. 95): "But Juvenal's xenophobia is not undiscriminating. For instance, the important passage in Satire VIII (112ff) shows some provincials sharply distinguished from others...”; Isaac (2004: p. 421): "It is clear, at any rate, that Juvenal's xenophobia focused on the immigrants from the eastern part of the empire, wherever they came from, while Gallia, Hispania, and Africa could evoke some admiration."; Courtney (1980: p. 27): "His xenophobia is striking but not indiscriminate."; Knox \& McKeown (2013: p. 541): "Juvenal's xenophobia is spectacular, a feature of his poetry that strikes modern readers with particular immediacy. It is not, however, universal - he expresses no prejudice against Gauls, Spaniards, and Africans, but he repeatedly attacks the Jews, Egyptians, and Greeks who are taking over Rome. Does this selective discrimination make it worse?"

3 Crompton (2003: p. 105). Further quotes on Juvenal's supposed xenophobia - without aiming to be exhaustive: Hopman (2003: p. 566): "In the context of the Satires, these connotations take on a precise meaning with regard to the strong xenophobia of Juvenal's persona (or personae) and his view of the role of the Greeks in the decline of patronage."; Geue (2013): "Perhaps Juvenal's famed xenophobia is alienating foreign scholarship.”; Tennant (1999: p. 6): "There are good grounds for believing that Juvenal himself was in fact an embittered and impoverished client, a conservative and xenophobic reactionary and a contemptuous critic of a decadent and delinquent Roman elite.”; Green (1972: p. 241): "Juvenal's xenophobia is not so much of the old-fashioned nationalist variety as that which we find in a trade unionist who sees his job threatened by immigrant labour. In this new urban rat-race he and his kind had either to compromise their principles, and beat the Greeks and freedmen at their own game, or go under." For the latter observation, see below the definition of xenophobia appearing in Wimmer (1997: p. 17).

4 Here, I would like to note that I consider the first person speaker of all of the Juvenalian poems as a single, unitary speaker (who can be regarded as a poetic persona) instead of presuming different personas for different satires. From this aspect, I follow the arguments of Iddeng (2000: pp. 107-129). When speaking about the supposed xenophobia of Juvenal, I speak about the features of his narrator (or persona) of course, and not of the author as a biographical person.

5 In this context, I use the term "foreigner" to denote non-Italian people appearing in the Satires. 
sion has a Greek origin meaning the "fear of strangers or foreigners", and the simpler definitions correspond to that. There are some more elaborated descriptions as well, for example the one appearing in certain documents of the UNESCO and the European Commission among others: "Attitudes, prejudices and behaviour that reject, exclude and often vilify persons, based on the perception that they are outsiders or foreigners to the community, society or national identity." 6 While the term xenophobia originally stood for an irrational fear, newer definitions contain the concept of hatred besides or instead of fear, similarly to the transformation of homophobia's definition. For instance, the Office of the United Nations High Commissioner for Human Rights focuses on malice instead of anxiety: "Manifestations of xenophobia include acts of direct discrimination, hostility or violence and incitement to hatred." The interpretation appearing in the summary of Andreas Wimmer's article Explaining xenophobia and racism is worth being quoted as well: xenophobic discourse is "an element of a political struggle about who has the right to be cared for by the state and society." ${ }^{8}$ When seeking for a unified concept of xenophobia, we can make a distinction between xenophobia and racism, even when using the latter in a broader sense, covering discrimination on not only physical, but cultural grounds as well: ${ }^{9}$ in a xenophobe it is not the pure existence of a foreigner that causes fear and/or hatred, but the presence of a foreigner in his country, in his city or society. ${ }^{10}$ And one final clarification before turning to the Satires: in accordance with the quoted definitions, I use both terms - "xenophobia" and "racism" - as containing a negative attitude (fear, hatred, etc.) per definitionem towards the person(s) involved beyond a simple notion of the difference, which is neither xenophobic, nor racist in itself if no negative (excluding, deprecating, blaming, mocking, etc.) connotations are attached to it. ${ }^{11}$

6 The website of the UNESCO cites this definition from the Declaration on Racism, Discrimination, Xenophobia, and Related Intolerance that was phrased in 2001, in Tehran (Declaration on Racism, Discrimination, Xenophobia and Related Intolerance against Migrants and Trafficked Persons. Asia-Pacific NGO Meeting for the World Conference against Racism, Racial Discrimination, Xenophobia and Related Intolerance. Teheran, Iran. 18 February 2001).

7 United Nations OHCHR (2013).

8 Wimmer (1997: p. 17).

9 E.g. in the definition of racial discrimination in the UN International Convention on the Elimination of All Forms of Racial Discrimination I.1.1: “...any distinction, exclusion, restriction or preference based on race, colour, descent, or national or ethnic origin which has the purpose or effect of nullifying or impairing the recognition, enjoyment or exercise, on an equal footing, of human rights and fundamental freedoms in the political, economic, social, cultural or any other field of public life."

10 While it is a debatable question if we can rely on our modern ideas like homophobia, xenophobia or racism in an ancient context, this analysis can be justified from two different aspects. On the one hand, the numerous appearances of the so-to-say charge of xenophobia in the research calls for the proving or the disproof of such "accusation", while on the other hand, the modern concept with its definitions presents us a theoretical framework for examining the image of the foreigner in the Satires. The latter, as I aim to prove, can also contribute to the understanding of Satire 3 and its central figure, the interlocutor named Umbricius.

11 Keeping this in mind, not all of the Juvenalian passages mentioning foreigners are relevant for this analysis; e.g. in 8.32-34 nothing more is said (or more precisely, referred to) about the Aethiopes than the colour of their skin: nanum cuiusdam Atlanta vocamus, / Aethiopem Cycnum, prauam extortamque puellam / Europen. 


\section{$* * *$}

In Juvenal's programmatic poem, Satire 1, foreigners appear as social climbers twice. cum pars Niliacae plebis, cum verna Canopi

Crispinus Tyrias umero revocante lacernas ventilet aestivum digitis sudantibus aurum nec sufferre queat maioris pondera gemmae... (1.26-29)

sed libertinus prior est. 'prior' inquit 'ego adsum. cur timeam dubitemve locum defendere, quamvis natus ad Euphraten' [...] nuper in hanc urbem pedibus qui venerat albis... (1.102-111)

The 'rich upstart' is one of the main targets of the Juvenalian invective, and accordingly this figure is represented in the programmatic poem multiple times. What is important to take notice of is the fact that foreigners appear in Satire 1 only in this context, but they are not the only ones who appear in this context - therefore, the foreigners are not rendered as worse than Romans here. The charges of xenophobia against the narrator of Satire 1 can arise from the references to these upstarts' past as slaves, as the word verna has (at least) a connotation suggesting this, while the reference in connection with the Syrian parvenu is even more direct. But we have to consider these utterances in their own contexts: while speaking about slavery in our society within an invective against a foreign person would be a really harsh xenophobic and racist attack, in a slaveholding society it is just a factual statement that emphasizes the gap between the former and the current social level of the depicted person. Pretty much the same can be said about Tiberius Iulius Alexander mentioned in a later passage of Satire 1:

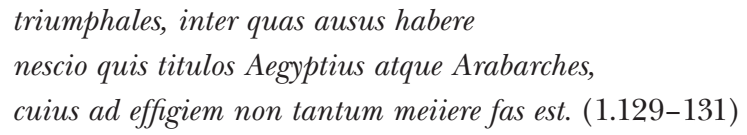

In the description of this man who has an effigy among the triumphal statues, not only the fact of his Egyptian origin is underlined, but his past as a customs (or taxation) officer is also highlighted - which is not a "low" office in itself, but its distance from being a triumphator can be regarded as great as the one between a barber and a wealthy parvenu, ${ }^{12}$ and thus the narrator points out the same type of difference again, the difference between the former and the current status.

While it is true that one of the central motifs of Satire 1 is that lofty upstarts and freedmen are gathering ground in Rome, the people of foreign origin are forming only a part of this process, and the narrator does not discriminate between Romans and

The blackness of skin appears in a similar context in 2.21-23.

12 See in 1.24-25: patricios omnis opibus cum provocet unus / quo tondente gravis inveni mihi barba sonabat... The authenticity of these lines is defended by Courtney (1980: p. 90), Braund (1996: p. 82), and Keane (2006: pp. 128-129), among others. 
non-Romans in any way apart from mentioning the origin of the latter. This happens three times while the whole poem attacks more than 20 different targets. ${ }^{13}$ The critical tone against foreigners appears together with the attack on Romans in multiple poems of Juvenal, thus their acts are forming only a part of the sins and ills of Rome, but by no means the cause. We can mention the introduction of Satire 3 as an example, where the desecration of Egeria's valley and the violation of the natural environment are partly caused by the Jews who are dwelling in the grove, but they had nothing to do with the artificial caves and the marbled streambank that deprived the formerly sacred place of its naturalness. ${ }^{14}$ In Satire 14, the Jews are mentioned as well briefly while presenting numerous examples of the parental influences on children.
quidam sortiti metuentem sabbata patrem
nil praeter nubes et caeli numen adorant,
nec distare putant humana carne suillam,
qua pater abstinuit, mox et praeputia ponunt;
Romanas autem soliti contemnere leges
Iudaicum ediscunt et servant ac metuunt ius,
tradidit arcano quodcumque volumine Moyses:
non monstrare vias eadem nisi sacra colenti,
quaesitum ad fontem solos deducere verpos. (14.96-104)

Although their religion and customs are by no means described in a flattering way here, it is only one example of parental influence in the satire, and it is far from the most detrimental or mischievous case presented. Thus, the foreigner is again represented only as being different, but not worse than the Roman. ${ }^{15}$

However, if we read Juvenal's words on the Jewish religion, it is hard not to notice the mockery in these lines. While according to my hypothesis, the Juvenalian narrator is not a characteristically xenophobic speaker, his intolerance towards other religions is obvious, which can be traced back to moral reasons. In the Satires, a direct connection is drawn between the moral decay of Rome and the fade and decline of the traditional Roman religion. ${ }^{16}$ And while it is true that the spread of Eastern religions is partly culpable

13 The attacked figures in the core of Satire 1 (lines 22-146): the marrying eunuch; Mevia, the hunting woman; the rich former barber; Crispinus; Matho, the lawyer; the one who informed on a powerful friend; Proculeius and Gillo, the gigolos; the despoiler of the prostituted orphan boy; the one convicted by an empty verdict; Marius Priscus (the latter two can be the same); the husband making profit from his wife's adultery; the young noble wasting his money on horses; the document forger; the poisoner matron; the seducer of his greedy daughter-in-law; the impure brides; the teenage adulterer; the gambler; the mean patron; the Syrian parvenu; the sportula-cheater; Tiberius Iulius Alexander; the glutton patron. Foreign origin is mentioned in only the three passages discussed above.

14 3.13-20: nunc sacri fontis nemus et delubra locantur / Iudaeis, quorum cophinus fenumque supellex / (...) in vallem Egeriae descendimus et speluncas / dissimiles veris. quanto praesentius esset / numen aquis, viridi si margine cluderet undas / herba nec ingenuum violarent marmora tofum.

15 Similarly, in 8.159-162, Juvenal mentions a Syrophoenician flatterer, which is one of the prominent sins in the Satires, committed by Romans and foreigners alike.

16 See Gellérfi (2012: pp. 121-123) among others. In 2.110-116 and 6.511-516, the narrator also mocks and 
for this, Juvenal does not pass over the responsibility of Roman citizens in silence; maybe it is enough to mention the Roman matrons of Satire 6 who engage in an orgy next to the altar of Pudicitia and then urinate on the statue of the goddess (6.306-313) or the depiction of the rites of Bona Dea not much later.

The latter poem, Satire 6 presents four passages that are worth examining. In 157-160, while enumerating the endless series of sins of Roman women, the narrator mentions an incest story from Judea and mocks the Jewish religion a bit, similarly to Satire 14:

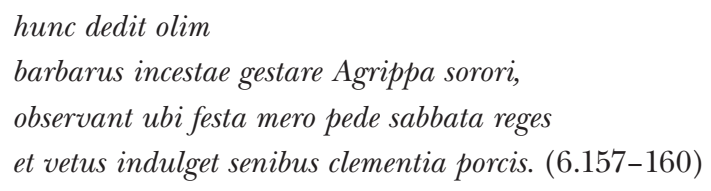

While these words are far from flattering, the story is much less elaborated than many others in the almost 700-line-long satire, and again: neither the event, nor the participants are rendered more scandalous than the Romans in any way. In the other three passages, the mention of the foreigners is only a device in the invective on Roman women. In the first one, the target are not the Greeks, but the matron who imitates the Greek language and habits (6.185-196); in the second one, not the Jewish and other Eastern religions and superstitions are attacked, but the women who waste money on these (6.508-564); while the skin of the new-born in line 600 is black because in that case adultery is obvious without any further clarification. ${ }^{17}$

Fear, one of the core elements of the concept of xenophobia, has to be discussed concerning two narratorial utterances about foreigners. In Satire 8, while speaking about the provinces, Juvenal makes a salty remark about the infirmity of the shaved-legged Greeks, ${ }^{18}$ but its context is far from negative as he expresses that the Greeks will hardly cause any problems to the governors of the provinces. Therefore, the motif of fear does not appear in this passage at all (neither that of hatred), but on the contrary, thus while this comment is biting and taunting, but not characteristically xenophobic, nor racist. Apart from Satire 15 (see below), there is only one comment of Juvenal's narrator where the fear of a foreigner is presented: in Satire 5, he compares two incomers of different origin based on their appearance.

tibi pocula cursor

Gaetulus dabit aut nigri manus ossea Mauri

attacks cults of foreign origin on moral grounds.

17 6.598-601: nam si distendere vellet / et vexare uterum pueris salientibus, esses / Aethiopis fortasse pater, mox decolor heres / impleret tabulas numquam tibi mane videndus.

18 8.112-117: despicias tu / forsitan inbellis Rhodios unctamque Corinthon / despicias merito: quid resinata iuventus / cruraque totius facient tibi levia gentis? / horrida vitanda est Hispania, Gallicus axis / Illyricumque latus... 
et cui per mediam nolis occurrere noctem,

clivosae veheris dum per monumenta Latinae.

flos Asiae ante ipsum... (5.52-56)

The frightening looks of the former slave strengthens the contrast between the treatment of Trebius and his patron, Virro. If we would examine the political correctness of Juvenal's narrator - which concept in my opinion cannot be applied to an ancient context -, this passage would provide a very strong argument against him; however, since the passage (and the whole satire) is built on the contrast between the meals of the two main characters, thus illustrating the maltreatment of Roman clients, the comparison of two foreign slaves cannot be understood as a xenophobic attack against any of them. It is also worth noting that Juvenal's narrator seems to be emphatic towards slaves in some other passages (e.g. 6.219-224; 14.15-22).

The strongest accusations of xenophobia against Juvenal originate in two poems: Satire 3 (discussed below) and Satire 15, which focuses on the crimes of a whole nation. This satire is a straightforward invective against the Egyptians, but it is absolutely not irrational, since all of the attacks are motivated by two reasons, both of which are in connection with morality. On the one hand, Juvenal scorns the Egyptian religion and connected beliefs and habits, ${ }^{19}$ which is always based on moral grounds in his poems, as I mentioned before; while on the other hand, he tells a story of cannibalism that is the central motif of the poem, ${ }^{20}$ the moral implications of which are needless to clarify. And it is also worth noting that out of his 16 satires only this one focuses on foreign people, while the other fifteen put the Romans in the spotlight.

When examining the appearances of foreigners in the Satires in detail, and comparing these passages with the descriptions of the Romans, the charge of xenophobia becomes less and less established. The foreigners living in the city sometimes serve only as a device for illustrating the crimes of Rome, and when the narrator attacks them, he does it only for the crimes and sins that are also committed by the Romans, making no difference between them apart from their origin. It is not an overstatement to claim that he treats them as integral parts of the wicked Roman society, at least from this aspect. The narrator never expresses that these people should not be in Rome, neither does he mention - except for a side-comment in Satire 5 - that he would be afraid of these people or that the Romans would be better in any aspect, and apart from the aforementioned religion, he does not even talk about the harmful effects of the customs and habits brought to Rome by such people. And moreover, in two different satires we can read about the contrary of the latter in connection with sexuality.

In the closure of Satire 2, Zalaces and his fellows arriving from the East, more precisely Armenia, are becoming truly corrupt in Rome before bringing this lewdness back to home, while in Satire 6, immorality is imported to Egypt from Rome by Eppia:

19 E.g. 15.1-3: Quis nescit, Volusi Bithynice, qualia demens / Aegyptos portenta colat? crocodilon adorat / pars haec, illa pavet saturam serpentibus ibin...

20 E.g. 15.77-81: labitur hic quidam nimia formidine cursum / praecipitans capiturque. ast illum in plurima sectum / frusta et particulas, ut multis mortuus unus / sufficeret, totum corrosis ossibus edit / victrix turba... 
venerat obses,

hic funt homines. nam si mora longior urbem

tindulsit $\uparrow$ pueris, non umquam derit amator.

mittentur bracae, cultelli, frena, flagellum:

sic praetextatos referunt Artaxata mores. (2.166-170)

nupta senatori comitata est Eppia ludum

ad Pharon et Nilum famosaque moenia Lagi

prodigia et mores urbis damnante Canopo. (6.82-84) ${ }^{21}$

The latter are thoughts hardly heard from a xenophobe, and it would be absolutely unimaginable to be heard from Umbricius, the interlocutor of Satire 3. The unsuccessful and disillusioned old man gives many reasons in his 300-line-long speech for leaving Rome, and one of the most prominent of his arguments is the large number of foreigners in his city. It is not a coincidence that Satire 3 is the most represented poem in studies dealing with Juvenal's xenophobia; ${ }^{22}$ however, it has to be emphasized that this disappointed old Roman has very different features from the narrator, ${ }^{23}$ and as I will present it, the attitude towards foreigners is one of these. Umbricius excludes them from his community, dividing the Roman society into "us" and "them". ${ }^{24} \mathrm{He}$ insults foreigners collectively; for example, when speaking about the Achaean faex ("dreg"), he feels that Rome lost its identity and calls his home a "Greek city":

\author{
quae nunc divitibus gens acceptissima nostris \\ et quos praecipue fugiam, properabo fateri, \\ nec pudor obstabit. non possum ferre, Quirites, \\ Graecam urbem. quamvis quota portio faecis Achaei? (3.58-61)
}

Umbricius also scorns the foreign culture, mentioning among the components of the "dreg" the city flooded by the habits, language, music and instruments of foreigners, and the prostitutes as well; but from another passage of the satire it seems that he refrains only from Eastern prostitutes. ${ }^{25}$ The struggle for common goods, which is the central motif of the xenophobia-interpretation quoted from Wimmer, is a recurring subject of his speech; moreover, he begins the whole monologue with this:

21 Furthermore, lines 64-66 of the Satire 6 can also be interpreted as referring to that the Greeks could learn a thing or two about lasciviousness in Rome, cf. Courtney (1980: pp. 270-271) on Thymele, whose name suggests Greek origin.

22 See in the first three footnotes.

23 In a former study, I examined this question in detail, see Gellérfi (2015: pp. 107-119).

24 3.92-93: haec eadem licet et nobis laudare, sed illis / creditur.

25 3.62-65: iam pridem Syrus in Tiberim defluxit Orontes / et linguam et mores et cum tibicine chordas / obliquas nec non gentilia tympana secum / vexit et ad circum iussas prostare puellas. Cf. 3.133-136: alter enim quantum in legione tribuni / accipiunt donat Calvinae vel Catienae, / ut semel aut iterum super illam palpitet; at tu, / cum tibi vestiti facies scorti placet, haeres / et dubitas alta Chionen deducere sella. 


\section{artibus honestis}

nullus in urbe locus, nulla emolumenta laborum,

res hodie minor est here quam fuit (3.21-23)

Umbricius' attitude towards foreigners is substantially different from that of the narrator. In his speech, Greeks, Egyptians and Eastern people are not rendered as equally guilty and sinful as the Romans, but as invading conquerors who are the main sources of moral and economic decay. His monologue is interwoven by inconsequent and unfair thoughts, as he is blindfolded by his hatred towards everyone who is not Roman, and he is extremely discriminative in defining the latter concept: for him only those are true Roman who were born in Rome to Roman parents. ${ }^{26}$ However, as I aimed to demonstrate, the principles and ideas that define his speech are not shared by the narrator of the Satires.

If the modern concept of xenophobia can be used in an ancient context, then in the Juvenalian Satires it is not the narrator (and even less the poet, of course) who should be named as a characteristically xenophobic speaker, but the interlocutor of Satire 3. This is another aspect from which a definite distinction has to be made between the narrator and Umbricius, who cannot be interpreted as an alter ego for the narrator or the poet as it was suggested before by certain scholars, nor as a mask that is put on by the satirist. ${ }^{27}$ The interlocutor is a complex figure from whom the narrator constantly keeps some distance. ${ }^{28}$ He presents himself as the manifestation of the true Roman values, but at the same time his figure incorporates the essence of the decaying Rome. In Satire 3, Juvenal presents the symptoms of the Roman decadence in two ways: a part of them is told by Umbricius in his monologue, while another part is presented by his figure. Thus, in this poem, Juvenal exhibits a narrow-minded xenophobic speaker, and therefore the xenophobia of Umbricius that was often used to prove that Juvenal himself and/or his narrator is a xenophobe, actually can disprove this charge. Of course, we cannot say that the Juvenalian narrator loves foreigners, but he does not love the Romans either, or anyone at all. But that does not make him a xenophobe, only a misanthrope.

\section{Bibliography}

Anderson, W. S. (1970). Lascivia vs. ira: Martial and Juvenal. California Studies in Classical Antiquity, 3, 1-34.

26 Braund (1996: pp. 233-234) exhibits the "dark side" of Umbricius following the interpretation of Winkler (1983: pp. 220-223). Staley (2000: p. 87) also emphasizes this aspect of the character. Hardie (1998: pp. 248-249) points out that Umbricius is unaware of certain historical processes, which can be traced back to his xenophobia.

27 The most important analyses of Umbricius: Motto \& Clark (1965: pp. 267-276); Anderson (1970: pp. 13-33); LaFleur (1976: pp. 383-431); Fruelund Jensen (1986: pp. 185-197); Braund (1990: pp. 502-506); Sarkissian (1991: pp. 247-258); Staley (2000: pp. 85-98).

28 See in detail in the aforementioned article: Gellérfi (2015: pp. 107-119). 
Bond, R. P. (1979). Anti-feminism in Juvenal and Cato. In C. Deroux (Ed.), Studies in Latin Literature and Roman History (pp. 418-447). Bruxelles: Latomus.

Braund, S. H. (1990). Umbricius and the Frogs (Juvenal, Sat. 3.44-5). The Classical Quarterly, 40, 502-506.

Braund, S. M. (Ed.). (1996). Juvenal: Satires, Book I. Cambridge: University Press.

Braund, S. M. (Ed.). (2004). Juvenal and Persius. Cambridge MA: Harvard University Press.

Courtney, E. (1980). A commentary on the Satires of Juvenal. London: Athlone.

Crompton, L. (2003). Homosexuality E Civilization. Cambridge MA: Belknap.

Fone, B. R. S. (2000). Homophobia: A History. New York: Metropolitan.

Fruelund Jensen, B. (1986). Martyred and Beleaguered Virtue: Juvenal's Portrait of Umbricius. Classica et Mediaevalia, 37, 185-197.

Gellérfi G. (2012). The Use of Statues to Represent Moral Decay in Juvenal's Satires. Acta Classica Universitatis Scientiarum Debreceniensis, 48, 117-124.

Gellérfi G. (2015). On the Sources of Juvenal's Satire 3. In Nagyillés J. et al. (Eds.), Sapiens Ubique Civis (pp. 107-119). Budapest: ELTE Eötvös József Collegium.

Geue, T. (Rev.). (2013). Biagio Santorelli: Giovenale, Satira IV: introduzione, traduzione e commento. Bryn Mawr Classical Review, 2013.01.21 [retrieved 07.05.2019 from http://bmcr.brynmawr. edu/2013/2013-01-41.html].

Green, P. (1972). Juvenal and his Age. In Idem, The Shadow of the Parthenon (pp. 216-267). Berkeley - Los Angeles: University of California Press.

Hardie, A. (1998). Juvenal, the Phaedrus, and the Truth about Rome. The Classical Quarterly, 48, 234-251.

Hopman, M. (2003). Satire in Green: Marked Clothing and the Technique of Indignatio at Juvenal 5.141-45. American Journal of Philology, 124, 557-574.

Iddeng, J. W. (2000). Juvenal, satire and the persona theory: some critical remarks. Symbolae Osloensis, 75, 107-129.

Isaac, B. (2004). The Invention of Racism in Classical Antiquity. Princeton: University Press.

Keane, C. (2006). Figuring Genre in Roman Satire. Oxford: University Press.

Knox, P. E., \& McKeown, J. C. (2013). The Oxford Anthology of Roman Literature. Oxford: University Press.

LaFleur, R. A. (1976). Amicitia and the Unity of Juvenal's First Book. Illinois Classical Studies, 4, 158-177.

Motto, A. L., \& Clark, J. R. (1965). Per iter tenebricosum: The Mythos of Juvenal 3. Transactions and Proceedings of the American Philological Association, 96, 267-276.

Sarkissian, J. (1991). Appreciating Umbricius: The Prologue (1-20) of Juvenal's Third Satire. Classica et Mediaevalia, 42, 247-258.

Staley, G. A. (2000). Juvenal's Third Satire: Umbricius' Rome, Vergil's Troy. Memoirs of the American Academy in Rome, 45, 85-98.

Tennant, P. M. W. (1999). Mask or mirror? A study of Juvenal's Satires as a reflection of authorial personality and perspective (PhD Diss.). University of Natal.

United Nations OHCHR (Office of the High Commissioner for Human Rights). (September 2013). Xenophobia [retrieved 07.05.2019 from https://nhri.ohchr.org/EN/Themes/Racial/Documents/Xenophobia.pdf]. 
Watts, W. J. (1976). Race Prejudice in the Satires of Juvenal. Acta Classica, 19, 83-104.

Wimmer, A. (1997). Explaining Xenophobia and Racism: A Critical Review of Current Research approaches. Ethnic and Racial Studies, 20, 17-41.

Winkler, M. M. (1983). The Persona in Three Satires of Juvenal. Hildesheim - Zürich - New York: Olms.

Dr Gergő Gellérfi PhD / gellerfigergo@gmail.com

Department of Cultural Heritage and Human Information Sciences

University of Szeged, Faculty of Humanities and Social Sciences

Egyetem u. 2, 6722 Szeged, Hungary 
